\title{
Correction to: Enhancing place-based learning progression through epistemic agency: a response to toward a hypothetical place-based learning progression for haze pollution in the Northern region of Thailand
}

\author{
Lezly Taylor $^{1} \cdot$ Brenda Brand $^{1}$
}

Published online: 6 October 2021

(c) The Author(s), under exclusive licence to Springer Nature B.V. 2021

\section{Correction to: Cultural Studies of Science Education (2021) 16:429-446 https://doi.org/10.1007/s11422-021-10022-2}

The article "Enhancing place-based learning progression through epistemic agency: a response to toward a hypothetical place-based learning progression for haze pollution in the Northern region of Thailand", written by Lezly Taylor and Brenda Brand, was originally published online on 12 May 2021 with Open Access under a Creative Commons Attribution 4.0 International License.

After publication, in volume 16, issue 2, page 429-446 the author(s) decided to cancel the Open Access. Therefore, the copyright of the article has been changed on 21 September 2021 to (C) The Author(s), under exclusive licence to Springer Nature B.V. 2021 with all rights reserved.

Publisher's Note Springer Nature remains neutral with regard to jurisdictional claims in published maps and institutional affiliations.

The original article can be found online at https://doi.org/10.1007/s11422-021-10022-2.

Lezly Taylor

lezly8@vt.edu

Brenda Brand

bbrand@vt.edu

1 School of Education, Virginia Polytechnic Institute and State University, Public Safety Building, Suite 201 (0313), 330 Sterrett Drive, Blacksburg, VA 24061, USA 